\title{
GAMBARAN REKAM MEDIS GIGI PUSKESMAS BAHU KOTA MANADO DITINJAU DARI STANDAR NASIONAL REKAM MEDIK KEDOKTERAN GIGI
}

\author{
Agung Prasetya Gunawan \\ Program Studi Kedokteran Gigi, Fakultas Kedoktean Universitas Sam Ratulangi
}

\begin{abstract}
ABSTRAK
Rekam medis merupakan salah satu bukti tertulis tentang proses pelayanan yang diberikan oleh dokter dan dokter gigi karena di dalam rekam medis berisi data klinis pasien selama proses diagnosis dan pengobatan. Rekam medis sangat penting dalam pelayanan bagi pasien karena data yang lengkap dapat memberikan informasi untuk menentukan keputusan dalam pengobatan, penanganan dan tindakan medis.

Penelitian ini bertujuan untuk mengetahui gambaran rekam medis gigi Puskesmas Bahu kecamatan Malalayang di kota Manado ditinjau dari Standar Nasional Rekam Medis Kedokteran Gigi.Populasi dalam penelitian ini adalah seluruh data rekam medis gigi di Puskesmas Bahu Kota Manado pada bulan Januari hingga Maret tahun 2012.

Hasil penelitian diperoleh bahwa rata-rata kelengkapan identitas pasien pada rekam medis gigi pasien yang ada di Puskesmas Bahu masih sangat kurang dan belum lengkap seperti tidak memiliki catatan kesehatan umum pasien, catatan odontogram dantabel jadwal kunjungan.
\end{abstract}

Kata kunci : rekam medis.

\section{ABSTRACT}

Medical recordsis one of the evidence of the services provided by doctors and dentists because in the medical record contains clinical dataof patients during the process of diagnosis and treatment. Medical records are very important in the service of the patient as a complete data can provide information for determining treatment decisions, treatment and medical treatment.

This study aims to describe dental medical records of Bahu Clinic of Manado in terms of the National Standard Medical Record Dentistry. The population in this study were all medical records in the health center dental Bahu Manado City in January to March 2012.

The result showed that the average completeness of medical records of the patient's identity on an existing dental patients in Bahu Clinic is still lacking and incomplete as not having general patient health records, tables odontogramand tables scheduled visit.

Keywords: medical records.

\section{PENDAHULUAN}

Seiring dengan makin berkembangnya dunia kesehatan di Indonesia, maka rekam medis mempunyai peranan penting dalam menunjang Sistem Kesehatan Nasional. Rekam medis merupakan salah satu bukti tertulis tentang proses pelayanan yang diberikan oleh dokter dan dokter gigi karena di dalam rekam medis berisi data klinis pasien selama proses diagnosis dan pengobatan. Pelayanan medis berbasis data sangat diperlukan guna ketepatan keberhasilan pengobatan yang diberikan. Data dan informasi pelayanan medis yang berkualitas serta terintegrasi dengan baik dan benar sumber utamanya adalah berasal dari data klinis rekam medis. ${ }^{1}$

Keberadaan rekam medis merupakan keharusan dalam penyelenggaraan praktik kedokteran, oleh karena itu setiap dokter dan dokter gigi diwajibkan untuk membuat rekam medis pasien yang dirawat. Rekam medis tersebut merupakan berkas yang berisi catatan dan dokumen identitas pasien, hasil pemeriksaan, pengobatan yang telah diberikan serta tindakan dan pelayanan lain yang telah diberikan kepada pasien. Rekam medis sangat penting dalam pelayanan bagi pasien karena data yang lengkap dapat memberikan informasi untuk menentukan keputusan dalam pengobatan, penanganan dan tindakan medis. $^{2}$

Kewajiban untuk membuat rekam medis telah diatur dalam Undang-undang nomor 29 tahun 2004 Tentang Praktik Kedokteran. Seorang dokter ataupun dokter gigi dalam menjalankan praktik pribadi maupun praktik di rumah sakit serta institusi pelayanan kesehatan lainnya diwajibkan membuat rekam medis. Melalui rekam medis yang dibuat maka seorang dokter maupun dokter gigi dapat mengetahui pelayanan kesehatan yang telah 
diberikan kepada pasien dan sebaliknya pasien dapat mengetahui tindakan yang telah dilakukan dokter pada dirinya, di samping itu juga rekam medis dapat menjadi ukuran terhadap mutu pelayanan yang diberikan. ${ }^{1,3}$

Tahun 2004 pemerintah melalui Direktorat Jenderal Pelayanan Medik Departemen Kesehatan telah menerbitkan Standar Nasional Rekam Medik Kedokteran Gigi. Standar ini dibuat mengingat pentingnya keberadaan data gigi-geligi setiap individu. Hal ini penting terutama bagi puskesmas sebagai garis depan bagi pelayanan kesehatan masyarakat. Keberadaan data gigi-geligi sangat dibutuhkan pemerintah teristimewa apabila terjadi bencana masal dan dibutuhkan adanya identifikasi korban yang berasal dari data gigi geligi pada odontogram di dalam rekam medis gigi.

Puskesmas Bahu merupakan salah satu puskesmas terbaik di Kota Manado yang memiliki lokasi di pusat kota serta memiliki jumlah pasien terbanyak dibandingkan puskesmas lainnya di Kota Manado. Keberadaan rekam medis gigi di puskesmas ini diharapkan dapat menjadi acuan untuk penilaian keberadaan rekam medis gigi pada puskesmas lainnya di kota Manado. Berdasarkan latar belakang di atas, penulis terdorong untuk melakukan penelitian deskriptif mengenai gambaran rekam medis gigi Puskesmas Bahu kota Manado ditinjau dari Standar Nasional Rekam Medis Kedokteran Gigi.

\section{METODE PENELITIAN}

Populasi penelitian Populasi dalam penelitian ini adalah seluruh data rekam medis gigi di Puskesmas Bahu Kota Manado pada bulan Januari hingga Maret tahun 2012.

Besar sampel minimal yang akan diambil menggunakan rumus Slovin, sebagai berikut:

$$
n=\frac{N}{N(d)^{2}+1}
$$

Keterangan:

$$
\begin{aligned}
\mathrm{n}= & \text { Besarnya sampel. } \\
\mathrm{N}= & \text { Besarnya populasi yang akan diteliti. } \\
\mathrm{d}= & \text { Penyimpangan terhadap populasi } \\
& \text { atau derajat ketepatan yang dinginkan, } \\
& \text { umumnya dipakai adalah } 0,05(5 \%) .
\end{aligned}
$$

Teknik pengambilan sampel dengan menggunakan metode Stratified Random Sampling yaitu sampel yang dilakukan dengan cara membagi populasi ke dalam kelompok-kelompok yang homogen. Setelah strata yang homogen dapat ditentukan, sampel dapat diambil secara acak (Simple Random Sampling) didapat jumlah sampel sebesar 836 responden.

\section{HASIL PENELITIAN}

Tabel 1. Distribusi subjek penelitianberdasarkan bulan

\begin{tabular}{lcc}
\hline Bulan & Responden & Sampel \\
\hline Januari & 300 & 98 \\
Februari & 239 & 79 \\
Maret & 297 & 94 \\
\hline Jumlah & 836 & 271 \\
\hline
\end{tabular}

Tabel 2. Distribusi data rekam medis gigi berdasarkan kelengkapan identitas pasien pada bulan Januari 2012

\begin{tabular}{ccccc}
\hline \multirow{2}{*}{$\begin{array}{c}\text { Kelengkapan } \\
\text { identitas pasien }\end{array}$} & \multicolumn{2}{c}{ Terisi } & \multicolumn{3}{c}{ Tidak terisi } \\
\cline { 2 - 5 } & $\mathrm{n}$ & $\%$ & $\mathrm{~N}$ & $\%$ \\
\hline Nama & 98 & 100 & 0 & 0 \\
\hline $\begin{array}{c}\text { Tempat, tanggal } \\
\text { lahir }\end{array}$ & 65 & 66,3 & 33 & 33,7 \\
\hline $\begin{array}{c}\text { Jenis kelamin } \\
\text { Pekerjaan }\end{array}$ & 17 & 17,3 & 81 & 82,7 \\
\hline Alamat rumah & 97 & 98,9 & 1 & 1,1 \\
\hline Rata - rata & 56,8 & 57,9 & 41,2 & 42 \\
\hline
\end{tabular}

Tabel 3. Distribusi data rekam medis gigi berdasarkan kelengkapan identitas pasien pada bulan Februari 2012

\begin{tabular}{ccccc}
\hline \multirow{2}{*}{$\begin{array}{c}\text { Kelengkapan } \\
\text { identitas pasien }\end{array}$} & $\mathrm{n}$ & $\%$ & $\mathrm{~N}$ & $\%$ \\
\cline { 2 - 5 } Nerisi & \multicolumn{3}{c}{ Tidak terisi } \\
\hline Nama & 79 & 100 & 0 & 0 \\
\hline $\begin{array}{c}\text { Tempat, tanggal } \\
\text { lahir }\end{array}$ & 46 & 58,2 & 33 & 41,8 \\
\hline $\begin{array}{c}\text { Jenis kelamin } \\
\text { Pekerjaan }\end{array}$ & 13 & 16,4 & 66 & 83,6 \\
\hline Alamat rumah & 77 & 97,4 & 2 & 2,6 \\
\hline Rata - rata & 43,8 & 55,4 & 35,2 & 44,5
\end{tabular}


Tabel 4. Distribusi data rekam medis gigi berdasarkan kelengkapan identitas pasien pada bulan Maret 2012

\begin{tabular}{ccccc}
\hline & \multicolumn{2}{c}{ Terisi } & \multicolumn{2}{c}{ Tidak terisi } \\
\cline { 2 - 5 } $\begin{array}{c}\text { Kelengkapan } \\
\text { identitas pasien }\end{array}$ & $\mathrm{N}$ & $\%$ & $\mathrm{~N}$ & $\%$ \\
\hline Nama & 95 & 100 & 0 & 0 \\
\hline $\begin{array}{c}\text { Tempat, tanggal } \\
\text { lahir }\end{array}$ & 61 & 64,2 & 34 & 35,8 \\
\hline Jenis kelamin & 9 & 9,5 & 86 & 90,5 \\
\hline Pekerjaan & 12 & 12,6 & 83 & 87,4 \\
\hline Alamat rumah & 94 & 98,9 & 1 & 1,1 \\
\hline Rata - rata & 54,2 & 57 & 40,8 & 42,9 \\
\hline
\end{tabular}

Tabel 5. Distribusi data rekam medis gigi berdasarkan kesehatan umum pasien pada bulan Januari - Maret 2012

\begin{tabular}{llccc}
\hline No & $\begin{array}{l}\text { Kelengkapan } \\
\text { data kesehatan }\end{array}$ & Terisi & $\begin{array}{c}\text { Tidak } \\
\text { terisi }\end{array}$ & $\begin{array}{c}\text { Jumlah } \\
\%\end{array}$ \\
\hline 1 & $\begin{array}{l}\text { Catatan } \\
\text { golongan darah }\end{array}$ & - & $\checkmark$ & 0 \\
\hline 2 & $\begin{array}{l}\text { Catatan terkait } \\
\text { darah normal }\end{array}$ & - & $\checkmark$ & 0 \\
\hline 3 & $\begin{array}{l}\text { Catatan penyakit } \\
\text { jantung }\end{array}$ & - & $\checkmark$ & 0 \\
\hline 4 & Catatan diabetes & - & $\checkmark$ & 0 \\
\hline 5 & $\begin{array}{l}\text { Catatan } \\
\text { haemofilia }\end{array}$ & - & $\checkmark$ & 0 \\
\hline 6 & Catatan hepatitis & - & $\checkmark$ & 0 \\
\hline 7 & $\begin{array}{l}\text { Catatan penyakit } \\
\text { lainnya }\end{array}$ & - & $\checkmark$ & 0 \\
\hline 8 & $\begin{array}{l}\text { Catatan alergi } \\
\text { obat-obatan }\end{array}$ & - & $\checkmark$ & 0 \\
\hline 9 & $\begin{array}{l}\text { Catatan alergi } \\
\text { makanan }\end{array}$ & - & $\checkmark$ & 0 \\
\hline \multicolumn{1}{c}{ Jumlah } & - & - & 0 \\
\hline
\end{tabular}

Tabel 6. Distribusi data rekam medis gigi berdasarkan tanggal pembuatan data pada bulan januari-maret 2012.

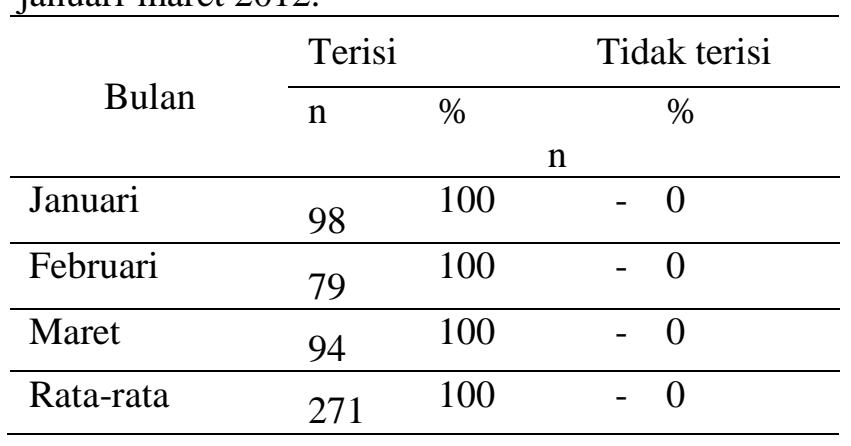

Tabel 7. Distribusi data rekam medis gigi berdasarkan kelengkapan catatan odontogram pada bulan januari-maret 2012

\begin{tabular}{clccc}
\hline No & $\begin{array}{l}\text { Kelengkapan } \\
\text { catatan } \\
\text { odontogram }\end{array}$ & Terisi & $\begin{array}{c}\text { Tidak } \\
\text { terisi }\end{array}$ & $\begin{array}{c}\text { Jumlah } \\
\%\end{array}$ \\
\hline 1 & Catatan oclusi & - & $\checkmark$ & 0 \\
\hline 2 & $\begin{array}{l}\text { Catatan torus } \\
\text { palatines }\end{array}$ & - & $\checkmark$ & 0 \\
\hline 3 & $\begin{array}{l}\text { Catatan torus } \\
\text { mandibularis }\end{array}$ & - & $\checkmark$ & 0 \\
\hline 4 & $\begin{array}{l}\text { Catatan } \\
\text { palatum }\end{array}$ & - & $\checkmark$ & 0 \\
\hline 5 & $\begin{array}{l}\text { Catatan } \\
\text { supernumerary } \\
\text { teeth }\end{array}$ & - & $\checkmark$ & 0 \\
\hline 6 & $\begin{array}{l}\text { Catatan } \\
\text { diastema }\end{array}$ & - & $\checkmark$ & 0 \\
\hline 7 & $\begin{array}{l}\text { Catatan gigi } \\
\text { anomaly }\end{array}$ & - & $\checkmark$ & 0 \\
\hline 8 & $\begin{array}{l}\text { Catatan lain- } \\
\text { lain }\end{array}$ & $\checkmark$ & 0 \\
\hline \multicolumn{1}{c}{ Rata-rata } & - & - & 0 \\
\hline
\end{tabular}


Tabel 8. Distribusi data rekam medis gigi berdasarkan kelengkapan catatan odontogram untuk tiap gigi pada bulan januari-maret 2011

\begin{tabular}{|c|c|c|c|c|}
\hline No & $\begin{array}{l}\text { Kelengkapan } \\
\text { catatan } \\
\text { odontogram } \\
\text { untuk tiap gigi }\end{array}$ & Terisi & $\begin{array}{l}\text { Tidak } \\
\text { terisi }\end{array}$ & $\begin{array}{c}\text { Jumlah } \\
\%\end{array}$ \\
\hline 1 & catatan 18 & - & $\checkmark$ & 0 \\
\hline 2 & catatan 17 & - & $\checkmark$ & 0 \\
\hline 3 & catatan 16 & - & $\checkmark$ & 0 \\
\hline 4 & catatan 15 & - & $\checkmark$ & 0 \\
\hline 5 & catatan 14 & - & $\checkmark$ & 0 \\
\hline 6 & catatan 13 & - & $\checkmark$ & 0 \\
\hline 7 & catatan 12 & - & $\checkmark$ & 0 \\
\hline 8 & catatan 11 & - & $\checkmark$ & 0 \\
\hline 9 & catatan 28 & - & $\checkmark$ & 0 \\
\hline 10 & catatan 27 & - & $\checkmark$ & 0 \\
\hline 11 & catatan 26 & - & $\checkmark$ & 0 \\
\hline 12 & catatan 25 & - & $\checkmark$ & 0 \\
\hline 13 & catatan 24 & - & $\checkmark$ & 0 \\
\hline 14 & catatan 23 & - & $\checkmark$ & 0 \\
\hline 15 & catatan 22 & - & $\checkmark$ & 0 \\
\hline 16 & catatan 21 & - & $\checkmark$ & 0 \\
\hline 17 & catatan 38 & - & $\checkmark$ & 0 \\
\hline 18 & catatan 37 & - & $\checkmark$ & 0 \\
\hline 19 & catatan 36 & - & $\checkmark$ & 0 \\
\hline 20 & catatan 35 & - & $\checkmark$ & 0 \\
\hline 21 & catatan 34 & - & $\checkmark$ & 0 \\
\hline 22 & catatan 33 & - & $\checkmark$ & 0 \\
\hline 23 & catatan 32 & - & $\checkmark$ & 0 \\
\hline 24 & catatan 31 & - & $\checkmark$ & 0 \\
\hline 25 & catatan 48 & - & $\checkmark$ & 0 \\
\hline 26 & catatan 47 & - & $\checkmark$ & 0 \\
\hline 27 & catatan 46 & - & $\checkmark$ & 0 \\
\hline 28 & catatan 45 & - & $\checkmark$ & 0 \\
\hline 29 & catatan 44 & - & $\checkmark$ & 0 \\
\hline 30 & catatan 43 & - & $\checkmark$ & 0 \\
\hline 21 & catatan 42 & - & $\checkmark$ & 0 \\
\hline \multirow[t]{2}{*}{32} & catatan 41 & - & $\checkmark$ & 0 \\
\hline & Rata-rata & - & - & 0 \\
\hline
\end{tabular}

Tabel 9. Distribusi data rekam medis gigi berdasarkan kelengkapan tabel jadwal kunjungan pada bulan januari-maret 2012.

\begin{tabular}{lllll}
\hline \multirow{2}{*}{ Bulan } & \multicolumn{2}{c}{ Terisi } & \multicolumn{2}{c}{ Tidak terisi } \\
\cline { 2 - 5 } & $\mathrm{N}$ & $\%$ & $\mathrm{n}$ & $\%$ \\
\hline Januari & 98 & 100 & - & 0 \\
\hline Februari & 79 & 100 & - & 0 \\
\hline Maret & 94 & 100 & - & 0 \\
\hline Rata-rata & 271 & 100 & 0 & $0 \%$ \\
\hline
\end{tabular}

\section{PEMBAHASAN}

\section{Distribusi data rekam medis gigi berdasarkan kelengkapan identitas pasien}

Pada hasil penelitian didapatkan bahwa ratarata rekam medis gigi pasien yang di isi berdasarkan kelengkapan identitas pasien pada bulan Januari-Maret 2012 di puskesmas Bahu masih sangat rendah. Kelengkapan identitas pasien memiliki manfaat besar bagi dokter maupun institusi kesehatan sehingga kelengkapan pengisian identitas pasien mutlak diisi oleh dokter / tenaga kesehatan yang menangani pasien tersebut. Ketepatan identifikasi pasien menjadi hal yang penting bahkan berhubungan dengan keselamatan pasien sehingga kesalahan karena keliru pasien merupakan hal yang dapat berakibat berhubungan dengan hukum. Ketepatan identifikasi pasien ini berdasarkan dengan kelengkapan identitas pasien. Selain itu kelengkapan identitas sangat penting dalam rekam medis gigi pasien karena rekam medis gigi dapat digunakan untuk membantu memberikan informasi kepada pihak yang berwajib untuk identifikasi korban bencana, dimana rekam medis gigi berfungsi sebagai data antemortem untuk dokter gigi forensik. ${ }^{4}$

\section{Distribusi data rekam medis gigi berdasarkan kesehatan umum pasien}

Pada bulan Januari hingga Maret 2012, data rekam medis gigi di puskesmas Bahu berdasarkan kesehatan umum pasien yang dapat dilihat pada Tabel 5 yaitu berjumlah $0,0 \%$. Hal ini sangat disayangkan karena riwayat medis pasien yang mendetail merupakan salah satu komponen utama dalam setiap rekam medis gigi pasien. Evaluasi riwayat dan informasi medis pasien sangat penting dalam menentukan ketepatan pemberian jenis perawatan untuk pasien. ${ }^{5}$

Tidak adanya riwayat kesehatan umum pasien dalam rekam medis gigi di puskesmas kemungkinan 
disebabkan oleh banyaknya pasien yang datang ke puskesmas sehingga para petugas kesehatan tidak memiliki banyak waktu untuk menanyakan tentang riwayat kesehatan umum pasien dan langsung melakukan tindakan perawataan gigi.

\section{Distribusi data rekam medis berdasarkan tanggal pembuatan data}

Pada Tabel 6, dapat dilihat bahwa data rekam medis gigi di puskesmas Bahu berdasarkan tanggal pembuatan data dari bulan Januari hingga Maret 2012 yakni sebanyak 271 responden (100\%) tidak dicantumkan tanggal pembuatan.

Semua informasi dalam rekam medis gigi harus ditulis dengan jelas dan orang yang menuliskan informasi baru dalam rekam medis tersebut harus menandatangani dan menulis tanggal masuknya informasi. ${ }^{4}$ Informasi dalam rekam medis gigi harus dilengkapi dengan tanggal pembuatan data. Hal ini tidak hanya meliputi catatan klinis dan catatan perkembangan pasien, namun juga riwayat medis dan dental, evaluasi fisik dan oral, rencana perawatan, informed consent, dan semua komunikasi dengan pasien termasuk percakapan lewat telepon. Informasi umum pasien juga sebaiknya diberikan tanggal, karena alamat dan informasi kontak pasien dapat berubah kapan saja. Tes laboratorium serta rujukan ke dokter ataupun tempat pelayanan kesehatan lainnya juga sebaiknya dilengkapi dengan tanggal. $^{5}$

\section{Distribusi data rekam medis berdasarkan kelengkapan catatan odontogram}

Pada bulan Januari hingga Maret 2012, data rekam medis gigi di puskesmas Bahu berdasarkan kelengkapan catatan odontogram berjumlah $0.0 \%$. Odontogram adalah suatu chart yang digunakan oleh dokter gigi untuk mendokumentasikan restorasi gigi yang dimiliki oleh pasien, serta untuk mencatat rencana restorasi gigi dan perawatannya. Odontogram dapat digambar dengan tampilan yang sangat mirip dengan gigi asli, atau dapat berupa gambaran yang sedikit abstrak. Gigi pada odontogram diberikan penomoran berdasarkan sistem FDI yaitu sistem yang digunakan di Indonesia. $^{6}$

Tidak adanya catatan odontogram dalam rekam medis gigi di puskesmas kemungkinan disebabkan tidak adanya formulir catatan odontogra serta kurangnya waktu yang dimiliki oleh petugas kesehatan karena banyaknya pasien yang datang, dan kemungkinan kurangnya kesadaran, pengetahuan para petugas kesehatan di puskesmas Bahu mengenai pentingnya pencatatan odontogram dalam rekam medis gigi pasien. Selain itu, juga mungkin disebabkan oleh tidak adanya evaluasi terhadap kelengkapan status rekam medis gigi pasien sehingga para petugas kesehatan sering melalaikan hal tersebut.

\section{Distribusi data rekam medis berdasarkan kelengkapan tabel jadwal kunjungan}

Pada Tabel 9, dapat dilihat bahwa data rekam medis gigi di puskesmas Bahu berdasarkan kelengkapan tabel jadwal kunjungan maka didapatkan sebesar $100 \%$ tidak memiliki tabel jadwal kunjungan. Kelengkapan tabel jadwal kunjungan memiliki manfaat besar bagi dokter maupun institusi kesehatan sehingga tabel jadwal kunjungan pasien wajib diisi oleh dokter atau tenaga kesehatan yang menangani pasien tersebut. Tabel jadwal kunjungan dapat membantu dokter untuk melakukan monitoring perawatan-perawatan yang telah diberikan kepada pasien sehingga dokter dapat menentukan rencana perawatan selanjutnya bagi pasien.

Pada saat pasien berkunjung untuk melakukan perawatan maka pasien sebaiknya diberikan pertanyaan pada setiap kunjungan untuk mengetahui status kesehatan dan obat-obatannya telah mengalami perubahan. Rekam medis gigi sebaiknya dilengkapi dengan jadwal tabel kunjungan yang selalu diperbarui. Status medis pasien sebaiknya dimonitor dengan interval yang sesuai dengan usia dan riwayat medis pasien. ${ }^{4}$

Rekam medis gigi yang selalu diperbarui merupakan kunci utama dalam proses identifikasi dental. Bencana tsunami yang terjadi di Asia Tenggara pada 26 Desember 2004 yang memakan korban lebih yang banyak telah membuktikan hal ini, dimana keberhasilan identifikasi korban sangat bergantung pada ketersediaan data antemortem dan postmortem yang akurat dan dapat dibandingkan. Gigi sering menjadi bagian tubuh terakhir yang tersisa dari korban, karena itu rekam medis gigi sangat diperlukan dalam identifikasi korban. ${ }^{7}$

Dalam bencana alam yang terjadi di Indonesia metode identifikasi korban dengan menggunakan gigi hampir tidak mungkin dilakukan, karena catatan rekam medis gigi sebagai data antemortem seringkali tidak tersedia. Karena itu, sangat penting untuk mengatasi hal ini, dengan meningkatkan kesadaran individu dan petugas kesehatan serta dokter gigi untuk membuat rekam medis gigi yang lengkap sebagai data antemortem. ${ }^{8}$

Permasalahan tidak adanya rekam medis gigi yang lengkap merupakan permasalahan yang paling sering terulang saat terjadi bencana alam, utamanya 
di negara-negara berkembang. Sama halnya dengan Indonesia, Thailand juga memiliki permasalahan dengan tidak tersedianya rekam medis gigi yang lengkap. Pada bencana alam tsunami tahun 2004 yang juga melanda Thailand, hanya $2 \%$ dari warga Thailand yang dapat diidentifikasi dengan menggunakan rekam medis gigi. Sangat berbeda dengan negara-negara Eropa dan Amerika, di mana para warga negara Eropa dan Amerika yang menjadi korban berhasil diidentifikasi sebanyak $76.4 \%$ dan $76.5 \%$ dengan menggunakan rekam medis gigi. ${ }^{9}$

Negara-negara yang memiliki rekam medis gigi antemortem yang lengkap seperti negara-negara di Eropa dan Amerika memiliki beberapa peraturan legislatif yang mengatur tentang penyimpanan rekam medis. Lebih lanjut, mereka seringkali mengukir nama pasien atau memberikan penomoran khas pada protesa gigi pasien. Di Inggris, Pusat Kesehatan Nasional memberikan kompensasi atau bayaran kepada dokter gigi yang memberikan label pada protesa gigi pasien mereka, dan di Amerika Serikat, ada paling sedikit 21 negara bagian yang mewajibkan dokter gigi untuk memberikan tanda pada protesa gigi untuk tujuan identifikasi forensik. Saat identifikasi korban bencana alam, negaranegara tersebut menunjukkan tingkat identifikasi dental yang sangat tinggi. Bahkan pada bencana alam tsunami, tim dari negara Kanada menggunakan teknologi internet untuk mengirimkan rekam medis antemortem sehingga semua warga negara Kanada yang menjadi korban dapat teridentifikasi. ${ }^{9}$

Sistem identifikasi dental untuk kebutuhan nasional di Indonesia belum dapat dijalankan dengan baik dan efisien karena kurangnya rekam medis gigi dan detail pencatatan yang tidak lengkap. Aturan hukum dan undang-undang mengenai pembuatan dan penyimpanan rekam medis sebaiknya lebih diperketat. Standarisasi rekam medis gigi nasional dan internasional juga sebaiknya direvisi secara efektif agar rekam medis gigi dapat digunakan dalam identifikasi gigi saat terjadi bencana alam multinasional. $^{9}$

Keberadaan rekam medis diperlukan dalam sarana pelayanan kesehatan, baik ditinjau dari segi pelaksanaan praktik pelayanan kesehatan maupun dari aspek hukum. Peraturan hukum yang berhubungan dengan pelaksanaan pelayanan kesehatan mencakup aspek hukum pidana, hukum perdata dan hukum administrasi. Dari aspek hukum, rekam medis dapat dipergunakan sebagai alat bukti dalam perkara hukum. Tidak tersedianya fasilitas rekam medis masih terjadi di beberapa tempat pada sarana pelayanan kesehatan. Hal ini menimbulkan permasalahan khususnya apabila terjadi tuntutan hukum yang berhubungan dengan pelaksanaan pelayanan kesehatan yang diberikan oleh tenaga kesehatan. ${ }^{10}$ Salah satu unsur utama dalam sistem pelayanan kesehatan yang prima adalah tersedianya pelayanan medis oleh dokter sesuai dengan amanah Undang-Undang Nomor 29 Tahun 2004 tentang Praktik Kedokteran. Dalam penyelenggaraan praktik kedokteran, setiap dokter wajib mengacu pada standar, pedoman dan prosedur yang berlaku sehingga masyarakat mendapat pelayanan medis secara profesional dan aman. Sebagai salah satu fungsi pengaturan dalam Undang-Undang Praktik Kedokteran yang dimaksud adalah pengaturan tentang rekam medis yaitu pada Pasal 46 dan Pasal 47. Bagi para tenaga kesehatan yang tidak membuat rekam medis akan diberikan sanksi hukum, disiplin dan etik. ${ }^{11}$

Sanksi pelanggaran yang dapat dijatuhkan atas pelanggaran tentang tidak tersedianya fasilitas rekam medis menurut Permenkes Rekam Medis Pasal 17 adalah sanksi administratif. Disamping itu, Pasal 79 Undang-Undang No.29/2004 tentang Praktik Kedokteran mengancam sanksi pidana kurungan paling lama 1 (satu) tahun atau denda paling banyak Rp.50.000.000,- (Lima puluh juta rupiah) setiap dokter atau dokter gigi yang dengan sengaja tidak memasang papan nama, tidak membuat rekam medis dan tidak memenuhi kewajiban. ${ }^{10}$

Sanksi-sanksi yang diberikan bagi dokter yang tidak membuat rekam medis diharapkan dapat memacu para dokter untuk tetap membuat rekam medis dalam setiap perawatan yang diberikan kepada pasien. Manfaat rekam medis sangat besar bagi dokter maupun pasien, selain itu rekam medis juga termasuk salah satu bahan baku Sistem Informasi Kesehatan (SIK), yang merupakan sumber daya non fisik manajemen kesehatan, untuk memperoleh data atau informasi yang akurat, lengkap dan mutakhir guna pemantauan pelayanan medik paripurna, yang merupakan dari Sistem Pencatatan dan Pelaporan Terpadu Puskesmas (SP2TP) serta merupakan indikator kinerja dari suatu puskesmas. ${ }^{11}$

Sistem pencatatan dan pelaporan terpadu puskesmas (SP2TP) adalah kegiatan pencatatan dan pelaporan data umum, sarana, tenaga dan upaya pelayanan kesehatan di puskesmas termasuk puskesmas pembantu, yang ditetapkan melalui surat keputusan Menteri Kesehatan RI No.63/Menkes/SK/II/1981. ${ }^{12}$ Sistem Pencatatan dan Pelaporan Puskesmas merupakan instrumen vital dalam sistem kesehatan. Informasi tentang kesakitan, penggunaan pelayanan kesehatan di puskesmas, kematian, dan berbagai informasi kesehatan lainnya berguna untuk pengambilan 
keputusan dan pembuatan kebijakan di tingkat kabupaten atau kota maupun kecamatan. Sistem Pencatatan dan Pelaporan Terpadu Puskesmas merupakan sumber pengumpulan data dan informasi ditingkat puskesmas. Segala data dan informasi baik faktor utama dan tenaga pendukung lain yang menyangkut puskesmas untuk dikirim ke pusat serta sebagai bahan laporan untuk kebutuhan. Pencatatan dan pelaporan mencakup: data umum dan demografi wilayah kerja puskesmas, data ketenagaan puskesmas, dan data sarana yang dimiliki puskesmas. $^{12}$

\section{KESIMPULAN}

1. Rata-rata kelengkapan identitas pasien pada rekam medis gigi pasien yang ada di Puskesmas Bahu masih sangat kurang dan belum lengkap.

2. Keseluruhan data rekam medis gigi dari bulan Januari hingga Maret 2012 di puskesmas Bahu tidak memiliki catatan kesehatan umum pasien, catatan odontogram dan tabel jadwal kunjungan.

3. Tidak lengkapnya catatan rekam medis gigi di puskesmas Bahu disebabkan tidak adanya formulir catatan odontogram, kurangnya waktu yang dimiliki petugas kesehatan karena banyaknya pasien yang datang, serta kurangnya kesadaran dan pengetahuan para petugas kesehatan di puskesmas mengenai pentingnya kelengkapan pencatatan dalam rekam medis gigi pasien, dan juga disebabkan tidak adanya evaluasi kelengkapan status rekam medis gigi pasien sehingga para petugas kesehatan sering melalaikan hal tersebut.

\section{DAFTAR PUSTAKA}

1. Pandu Y. Undang-Undang RI Nomor 29 Tahun 2004. Jakarta :Penerbit Indonesia Legal Center Publishing; 2009.

2. Agung rakhmawan. Rekam Medis (Permenkes No: 269/Menkes/Per/III/2008). [online] 2011 [cited 2011 Agust 12]; [82 screens]. Available from :http:/agungrakhmawan.wordpress.com/doc /2-11/08/08/rekam-medis-permenkes.

3. Dirjen Bina Pelayanan Medik Depkes RI. Standar Nasional Rekam Medik Kedokteran Gigi. Jakarta :Depkes RI; 2007.

4. American Dental Association. Dental Records. [online] 2010. Available from: http//:www.ada.org.

5. Hinrisch, R Mark. Christensen, Mark L. Shampaine, Guy S. Reitz, Lili. The Dental Patient Record. American Association of Dental Examiners; June 2009.
6. What is an odontogram? [online] 2012. Available from http://wiki.answers.com/Q/What is i $\mathrm{t}$ an odontogram\#ixzz20cDunvX3

7. Dierickx, A. Seyler, M. De Valck, E. Wijffels, J. Willems, G. Dental Records: A Belgium Study. The Journal of Forensic OdontoStomatology, Vol.24 No.1, June 2006.

8. Soedarsono, N. Untoro, E. Quendangen, AR, Atmadja, DS. The Role of Forensic Odontology in Personal Identification: Indonesian Perspective. Indonesian Journal of Legal and Forensic Sciences Vol.1 No.1, 2008.

9. Petju, M. Suteerangyongprasert, A. Thongpud, R. Hassiri, K. Importance of dental records for victim identification following the Indian Ocean tsunami disaster in Thailand. Journal of The Royal Institute of Public Health Vol.121 No.4, April 2007.

10. Wahjuningati, Edi. Rekam Medis dan Aspek Hukumnya [online] 2010 [cited 2010 Nov 11]. Available from http//:www.sap.ubhara.ac.id/wpcontent/.../rekam-medis.pdf.

11. A.P, Christopher, Dwindra, Mayenru. Saputra, Roni Eka. Melinda, Vivi. Optimalisasi Pengisian Rekam Medis Dalam Rangka Meningkatkan Mutu Pelayanan Kesehatan di Poliklinik Dewasa Puskesmas Harapan Raya. Faculty of Medicine, University of Riau. Pekanbaru, Riau; 2009.

12. Iswanto, Joni. Sistem Pencatatan dan Pelaporan Puskesmas [online] 2012 [cited 2012 Juni 14]. Available from http://sumbarsehat.blogspot.com/2012/06/ sistem-pencatatanpelaporanpuskesmas.html. 